УДК 656.212.7.073

\title{
ПЕРСПЕКТИВИ ОРГАНІЗАЦІЇ МЕРЕЖІ МУЛЬТИМОДАЛЬНИХ ТЕРМІНАЛІВ НА ТЕРИТОРІї УКРАЇНИ
}

Канд. техн. наук В.В. Петрушов

\section{ПЕРСПЕКТИВЫ ОРГАНИЗАЦИИ СЕТИ МУЛЬТИМОДАЛЬНЫХ ТЕРМИНАЛОВ НА ТЕРРИТОРИИ УКРАИНЫ}

Канд. техн. наук В.В. Петрушов

\section{PROSPECTS OF ORGANIZATION NETWORK OF MULTIMODAL TERMINALS IN UKRAINIAN AREA}

\section{Candidate tehn. sciences V. Petrushov}

У статті наведено аналіз сучасного стану комбінованих перевезень в Україні, розглянута технологія взаємодії різних видів транспорту при використанні логістичних принщипів, а також можливість організації мережі мультимодальних терміналів.

Ключові слова: мультимодальні термінали, логістичний ланц̧юг, технологічний графік, інтермодальні перевезення.

В статье приведен анализ современного состояния комбинированных перевозок в Украине, рассмотрена технология взаимодействия разных видов транспорта при использовании логистических принципов, а также возможность организации сети мультимодальных терминалов.

Ключевые слова: мультимодальные терминаль, логистическая цепочка, технологический график, интермодальные перевозки.

The article is an analysis of the current state of combined transport in Ukraine.yu the technology of the interaction of different types of tarnsporta using logistic principles, as well as the possibility of organizing a network of multimodal terminals.

The questions about the development of a single graphics technology that optimizes the time to file and cleaning vehicles. Also developed a classification of multi-modal terminals, depending on the volume of work performed.

Keywords: multi-modal terminals, the supply chain, process chart, intermodal transportation.

Вступ. У сучасних умовах розвитку ринкової економіки та міжнародної торгівлі транспорт відіграє дуже важливу роль. На передній план виходять логістичні принципи: доставлення «від дверей до дверей», «точно в строк» та «у повному обсязі». Однак для більшості клієнтів виконати ці принципи за допомогою перевезень одним видом транспорту (унімодальні перевезення) не можливо. Тому високих темпів набирає розвиток комплексних перевезень, тобто мультимодальних та інтермодальних. Ці перевезення передбачають забезпечення чіткої взаємодії між різними видами транспорту, які беруть участь у процесі транспортування вантажу. Тому існує потреба в організації єдиних центрів, які будуть координувати цю взаємодію, тобто логістичних або мультимодальних терміналів [1]. 
Постановка проблеми у загальному вигляді та її зв'язок із важливими науковими та практичними завданнями. Перевезення, які здійснюються різними видами транспорту, але за одним перевізним документом, набувають зараз значного поширення. Такий спосіб дає змогу економити час на оформлення документів при перевалці вантажів. Однак виникають певні труднощі: існуючі перевалочні комплекси важко назвати мультимодальними терміналами у повному сенсі цього слова, швидше це великі складські комплекси, у яких $є$ під'їзні шляхи та відповідні технічні засоби. Однак немає основного - узгодженого технологічного процесу, який дав би змогу оптимізувати обмінні операції між різними видами транспорту для скорочення простоїв рухомого складу.

$$
\text { Аналіз часу знаходження }
$$

транспортних одиниць на існуючих терміналах показує, як він розподіляється за кожними технологічними операціями (рисунок).

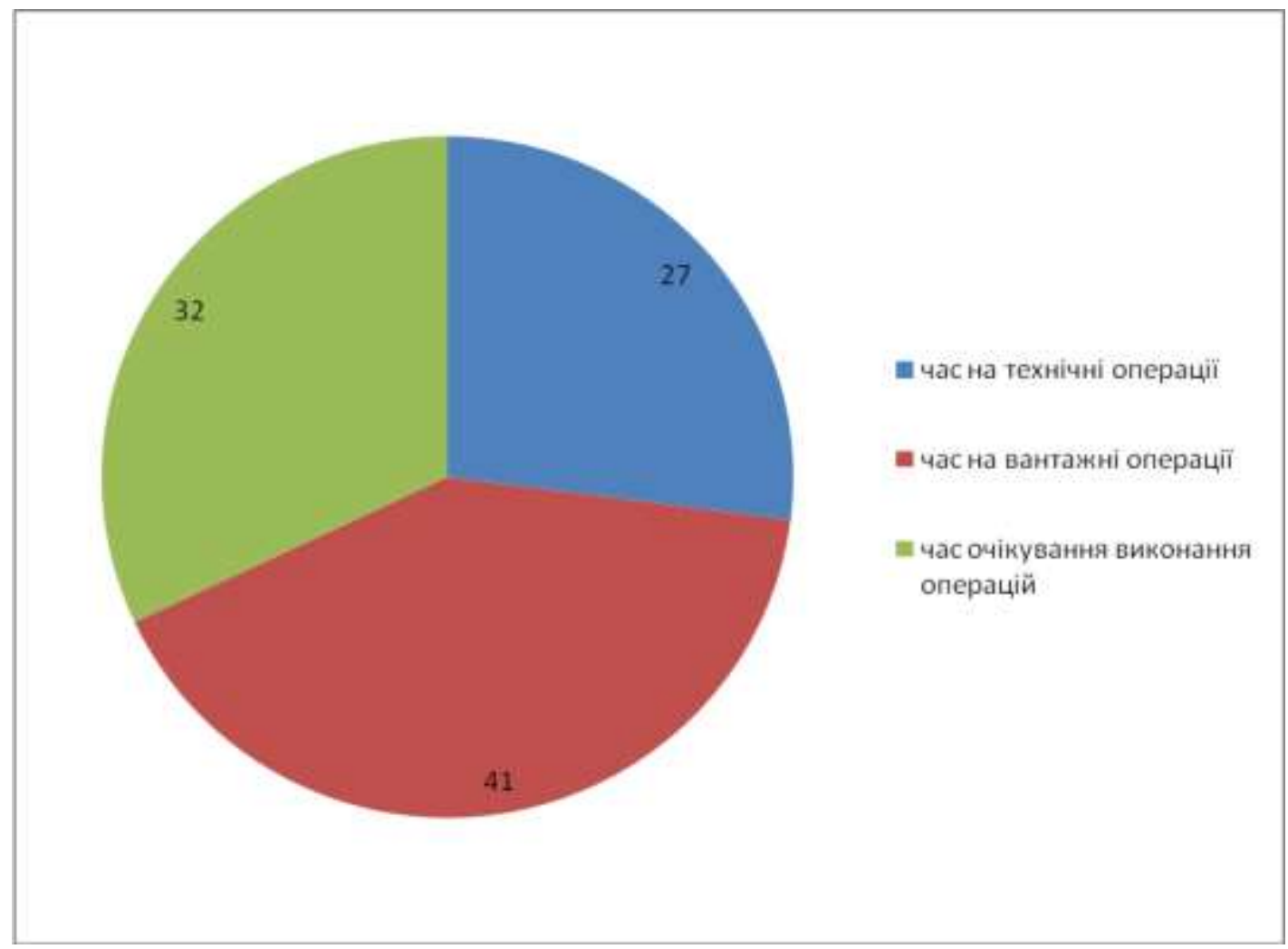

Рис. 1. Розподіл часу на технологічні операції на сучасному терміналі

Виходячи 3 наведених даних бачимо, що третину часу рухомий склад перебуває в очікуванні подавання для виконання вантажних операцій. Це відбувається через те, що графік виконання технологічних операцій розробляється для кожного з видів транспорту окремо.

Однак проаналізувавши розробки, які були виконані у цьому напрямку, можна зробити такі висновки:
- логістичні центри та їх різновид «сухі порти» не розглядаються у розрізі міжнародних перевезень та міжнародних транспортних коридорів;

- логістичні ланцюги розглядаються, як правило, для кожного виду транспорту окремо;

- при оптимізації основну увагу приділяють навантажувальнорозвантажувальним операціям, а технологія перевезень та простої транспортних 
одиниць через нетехнологічні операції розглядаються лише поверхнево;

- на даний момент усі варіанти єдиного технологічного процесу недостатньо враховують взаємодію різних видів транспорту (розроблені лише контактні графіки для взаємодії під'їзних та магістральних колій або лише взаємодія атомобільного транспорту та залізниці).

Аналіз останніх досліджень i публікацій. У деяких сучасних розробках $[2,3]$ запропонована ідея логістичного центру «сухий порт». У класичному змісті [4] ця технологія передбачає винесення операцій 3 контейнерами, вагонами або автомобілями за межі морського або річкового порту. Це дає можливість вивільнити припортові території від транспортних одиниць, які простоюють в очікуванні обробки, зменшити витрати на обслуговування та скоротити час на нетехнологічні операції. Однак у сучасних умовах [5] «сухий порт» починає розглядатися як термінал, відділений від водного порту. Це дає можливість більш вільно використовувати цей термін, причому він усе частіше характеризує взаємодію автомобільного та залізничного транспорту.

Ідея подання мультимодального терміналу як логістичного центру наведена у [6]. У цій роботі аналізуються потужності контейнерних терміналів та можливості покращення обслуговування при використанні логістичних принципів у процесі узгодження роботи різних видів транспорту (залізничного, автомобільного, морського).

Визначення мети та задачі дослідження. Проаналізувавши існуючу ситуацію, можна сформулювати мету дослідження як розроблення моделі організації мережі мульти- та інтермодальних терміналів. Задачі полягають у розробленні єдиного технологічного графіка роботи такого терміналу, визначенні його потужності та розташування на транспортній мережі України.
Основна частина дослідження. Технологічний графік повинен враховувати особливості виконання вантажних операцій 3 відповідними рухомими одиницями транспорту для кожного виду транспорту. Найбільші проблеми виникають через різну вантажомісткість транспортних засобів. Так, середня вантажопідйомність автомобіля складає $10 \mathrm{~T}$, залізничного вагона - $60 \mathrm{~T}$, а корабля - від $5000 \mathrm{~T}$. Звичайно це призводить до того, що час на виконання вантажних операцій буде різний. У загальному вигляді цей час можна розрахувати таким чином:

$$
t_{\text {вант }}=\frac{m_{m 3}}{m_{\text {нав }}},
$$

де $m_{m з}$ - вантажомісткість транспортного засобу, т;

$m_{\text {нав }}{ }^{-}$навантажувальна потужність терміналу для відповідного виду транспорту, т/год.

Тому кількість транспортних засобів, які можуть бути завантажені протягом доби, складає

$$
N=] \frac{24-t_{\text {mеx }}}{t_{\text {вант }}}[\text {, }
$$

де $t_{\text {mex }}$ - час на виконання операцій, які не пов'язані 3 навантаженням та вивантаженням.

Виходячи 3 вищенаведеного можна зробити висновок, що кількість транспортних засобів різного виду транспорту, які можуть бути оброблені протягом доби, не буде однаковою.

Виходячи 3 того, що майже третина часу на сучасному терміналі витрачається на очікування виконання вантажних операцій, необхідно розглянути більш детально, з яких елементів складається цей простій. 
Час на очікування виконання операцій можна розділити на технологічний (тобто передбачений технологією роботи) i нетехнологічний (тобто простій, який виникає через неузгодженість у діях). До першого виду можна віднести: простої, пов'язані 3 необхідністю переміщення НРМ; час, що необхідний для подавання рухомих одиниць для виконання операцій; час на додаткові операції, пов'язані 3 оформленням необхідних документів перед виконанням операцій. Другий вид - це додаткові простої, що виникають через відсутність рухомих одиниць під навантаження, відсутність вантажу, зайві простої через неможливість подавання рухомих одиниць (наприклад, відсутність локомотива для подавання вагонів) і т.п. Саме через це виникають такі значні простої рухомих одиниць на сучасних перевантажувальних комплексах.

Така ситуація зумовлена у першу чергу самим принципом організації роботи. На терміналах, які працюють зараз на території України, як правило, застосовується принцип роздільного управління, тобто кожним видом транспорту керує окремий працівник. Звичайно, при такій схемі різко звужуються можливості гнучкого реагування, а також «вмикається» принцип розділення відповідальності між цими керівниками. Щоб запобігти таким ситуаціям, необхідно використовувати принципи $а$-модальності, тобто єдиного диспетчерського управління.

Переваги, які надасть такий спосіб:

1) концентрація управління та відповідальності в одних руках;

2) скорочення витрат на утримання управлінського персоналу;

3) можливість більш швидкого та гнучкого реагування на проблеми, що виникають у роботі.

Результатом упровадження єдиного диспетчерського центру повинно стати скорочення нетехнологічних (a y перспективі і технологічних) простоїв рухомих одиниць.
Оскільки мультимодальні термінали призначені для обслуговування значних вантажних потоків, що курсують різними видами транспорту, найбільш раціонально розташовувати їх на місцях перетину транспортних потоків. Як найкраще для цього підходять транспортні вузли, які вже мають деяку інфраструктуру, яка дає змогу здійснювати взаємодію різних видів транспорту.

Міжнародний досвід організації мультимодальних терміналів у Європі, США, Китаї свідчить про те, що для забезпечення безперебійної взаємодії різних видів транспорту необхідно забезпечувати чітке виконання вантажних, технічних та комерційних операцій. На даний момент існують такі типи терміналів відповідно до видів транспорту:

1) автомобільно-залізничний;

2) автомобільно-водний;

3) залізнично-водний;

4) залізнично-автомобільно-водний;

5) залізнично-автомобільно-повітряний.

Виходячи 3 того, які види транспорту обслуговує термінал, він повинен мати відповідні пристрої для приймання рухомих одиниць (залізничні колії, автошляхи, портові пристані, злітнопосадочні смуги), пристрої для виконання вантажних операцій та для обслуговування клієнтів. Сучасні технології перевантаження передбачають два типи обслуговування:

1) крос-докінг, або пряме перевантаження;

2) перевантаження через склад.

Виходячи 3 того, яка технологія переважає в роботі терміналу, розраховуються необхідні складські площі, кількість навантажувальнорозвантажувальних пристроїв та обслуговуючого персоналу. Тому термінал можна описати параметричною функцією

$$
T=\left(\Pi, N_{\text {нрм }}, N_{n p}\right),
$$


де П - площа складських приміщень, яка являє собою сумарну площу платформ для прямого перевантаження та складів, що призначені для тривалого зберігання вантажу;

$N_{\text {нрм }}$ - кількість навантажувальнорозвантажувальних машин;

$N_{n p}$ - кількість працівників терміналу, які обслуговують вантажопотік.

Основною проблемою існуючих терміналів $з$ обслуговування різних видів транспорту є відсутність при їх управлінні логістичних принципів. Кожен вид транспорту обслуговується майже автономно i це призводить до значних простоїв рухомого складу, неповного використання потужностей та ускладнення процесу обробки вантажу. Тому для ефективної роботи терміналу необхідна організація логістичного центру, який буде координувати діяльність комплексу для отримання максимального прибутку.

Створення мережі мультимодальних терміналів спрямоване на прискорення процесу транспортування вантажу в логістичній моделі «від дверей до дверей». У такій системі перевізник, що здійснює доставлення вантажу, може надати більш якісні послуги та більш оперативно керувати процесом транспортування.

Для створення логістичного ланцюга необхідно вичленити основні операції, які здійснюються в процесі доставлення вантажу, і встановити зв'язки між ними. Це дає змогу організувати координацію дій усіх видів транспорту. Для чіткої взаємодії слід розробити графік єдиного технологічного процесу. Цей графік дасть змогу встановити час на виконання всіх необхідних операцій для кожного виду транспорту.

Система мультимодальних терміналів призначена для обслуговування вантажопотоків, які переміщуються по основних напрямках. У першу чергу необхідно забезпечити обслуговування міжнародних потоків, які переміщуються через територію України. Тому основні термінали необхідно розташовувати на маршруті прямування основних транзитних потоків, що прямують через міжнародні транспортні коридори. Вони стануть віссю мультимодальної мережі терміналів, від якої будуть розподілятися менш значущі напрямки по інших регіонах.

Основними завданнями системи мультимодальних терміналів є:

1. Покращення взаємодії різних видів транспорту, які беруть участь у перевезенні вантажу.

2. Збільшення обсягів прямих змішаних перевезень як усередині країни, так і у міжнародному сполученні.

3. Концентрація роботи з вантажем у великих комплексах, що дає змогу зменшувати накладні витрати та забезпечувати більш розвинену інфраструктуру.

4. Створення єдиної системи документообігу усередині мережі, що дасть можливість прискорення обробки вантажів.

5. Створення «зеленого коридора» для транзитних вантажів, що перевозяться у рамках міжнародних транспортних коридорів.

6. Реалізація логістичних принципів «від дверей до дверей», «доставлення точно в строк» та «у повному обсязі».

Для реалізації цих завдань необхідно створити єдину мережу мультимодальних терміналів, поєднаних між собою технологічними та інформаційними зв'язками. Відповідно до функцій та розмірів термінали можна класифікувати таким чином:

1) термінали класу $\mathrm{A}$ - це термінали, які мають великі площі та переробляють значні вантажопотоки. У таких центрах $\epsilon$ значні обсяги як перевантаження за прямим варіантом, так і складування вантажу;

2) термінали класу В. Такі термінали переробляють значні обсяги вантажопотоків, але мають незначні складські площі. Це означає, що більша 
частина вантажу переробляється за прямим варіантом;

3) термінали класу C - це комплекси з відносно невеликими обсягами вантажу та складськими площами.

Виходячи 3 вищенаведеного можна зробити висновок, що термінали класу А повинні розташовуватися у місцях, де спостерігається концентрація вантажовідправників та вантажоодержувачів, тобто у великих транспортних вузлах (Харків, Донецьк, Дніпропетровськ). Термінали класу В найбільш доцільно розташовувати на перехрещенні значних транзитних вантажопотоків або у точках перевантаження 3 одного виду транспорту на інший, причому основним питанням $\epsilon$ забезпечення технології крос-докінгу (вузли на вхідних точках мережі або у місцях, де відбувається інтенсивне перевантаження на інші види транспорту). Термінали останнього класу розташовуються у невеликих вузлах та у місцях концентрації потоків невеликих обсягів (переважно в аграрних районах).

Виходячи 3 вищенаведеного постає задача про визначення оптимальної конфігурації мережі. Для іiі вирішення пропонується використання теорії графів [7]. За вершини приймаються мультимодальні термінали, а за ребра з'єднувальні шляхи (автомобільні, залізничні).

Теорія графів дає можливість сформувати мережу таким чином, щоб досягнути мінімальних капітальних та експлуатаційних витрат. Для вирішення такої задачі доцільно використовувати граф типу «дерево», тобто граф, у якому вершини поєднані таким чином, що відсутні цикли. У такому випадку сумарна довжина шляхів буле мінімальною, тому і капітальні витрати будуть зведені до мінімуму.

Мережа мультимодальних терміналів може бути описана формулою

$$
F(Q)=f\left(V_{\text {терм }}, L_{3}, t_{\text {nер }}\right) \rightarrow \max ,
$$

де $Q$ - розмір вантажопотоку, який переробляється мережею мультимодальних терміналів, т;

$V_{\text {терм }}$ - кількість терміналів у мережі, які беруть участь у переробці вантажопотоку;

$L_{3}$ - довжина з'єднувальних колій між терміналами, км;

$t_{n e p} \quad-$ час на переміщення вантажопотоку між терміналами, од. часу.

Тобто задача полягає у створенні такої мережі мультимодальних терміналів, яка б забезпечила максимальну пропускну спроможність, тобто перевезення максимальної кількості вантажу. У той же час цю задачу можна інтерпретувати інакше: визначити максимальну кількість вантажу, яка може бути перевезена через існуючу кількість терміналів, або прокласти маршрут таким чином, щоб відстань перевезення була мінімальною. Такі задачі можна вирішувати за допомогою графа типу екстремального дерева.

Висновки 3 дослідження i перспективи, подальший розвиток $\mathbf{y}$ даному напрямку. У підсумку можна зробити певні висновки:

1. Створення мережі мультимодальних терміналів на маршруті переміщення імпортного та експортного вагонопотоку дасть змогу прискорити його просування, а також покращити обслуговування клієнтів за рахунок надання комплексних послуг за схемами «доставлення від дверей до дверей», «точно в строк» та «у повному обсязі». Збільшення обсягів інтермодальних перевезень дасть змогу залучити додаткові обсяги вантажопотоків, що можливо досягнути за рахунок зменшення собівартості перевезення (за умови скорочення експлуатаційних витрат на обслуговування потоків у місцях перевантаження). 
2. Вибір місця розташування мультимодального терміналу повинен здійснюватися не тільки виходячи 3 розвитку інфраструктури (як пропонується у багатьох роботах - у транспортних вузлах), а й ураховуючи переважні маршрути, які проходять по основних напрямках. Не виключені випадки, коли створення окремого терміналу $\epsilon$ більш ефективним, ніж використання існуючих потужностей.

3. Нормальне функціонування мережі терміналів неможливе без створення єдиної інформаційно-керуючої системи, яка б давала змогу координувати їх діяльність та перерозподіляти вантажопотоки.

4. Усі термінали можуть розподілятися на класи у залежності від обсягів роботи, які вони виконують. Залежно від того, до якого класу належить термінал, розробляється відповідна технологія роботи.

5. Для вирішення задачі щодо розташування терміналів на мережі доцільно використовувати граф типу екстремального дерева. Такий граф дає можливість також вирішувати задачу про максимальний обсяг вантажопотоку, який може бути перероблений мережею.

\section{Список використаних джерел}

1. Ломотько, Д.В. Формування транспортного процесу залізниць України на базі логістичних принципів [Текст]: автореф. дис... д-ра техн. наук: 05.22.01/Ломотько Денис Вікторович. - Харків: УкрДАЗТ, 2008. - 38 с.

2. Панкратов, В.І. Організація та управління системою промислового залізничного транспорту на основі принципів логістики [Текст]: автореф. дис... канд. техн. наук: 05.22.01/ Панкратов Володимир Іванович. - Харків: УкрДАЗТ, 2009. - 20 с.

3. Бауліна, Г.С. Удосконалення роботи прикордонних передавальних станцій на основі автоматизованої технології управління вагонопотоками [Текст]: автореф. дис... канд. техн. наук: 05.22.01/ Бауліна Ганна Сергіївна. - Харків: УкрДАЗТ, 2012. - 20 с.

4. Höltgen, D. Terminals, intermodal logistics centres and European infrastructure policy [Текст]/D. Höltgen //Dissertation, European Centre for Infrastructure Studies.

5. Панова, Ю.Н. Факторы строительства тыловых контейнерных терминалов [Текст] / Ю.Н. Панова, Е.К. Коровяковский // Вестник Тихоокеанского государственного университетаю. - 2012. - № 1. - С. 103-112.

6. Нерман, А.А. Логистические методы и технологии организации и планирования работы контейнерного терминала [Текст]: автореф. дисс... канд. экон. наук / А.А. Нерман. СПБ., 2009. - 19 с.

7. Сигорский, В.П. Математический аппарат инженера [Текст] / В.П. Сигорский. - К.: Техника, 1975. - 766 с.

Рецензент д-р техн. наук, професор О.В.Лаврухін

Петрушов Василь Володимирович, кандидат техн. наук, доцент кафедри управління експлуатаційною роботою Української державної академії залізничного транспорту. Тел.: (057) 730-10-88. E-mail: vv1_81@mail.ru

Petrushov Vasily Vladimirovich, candidate tehn., assistant of management of the operational work of the Ukrainian State Academy of Railway Transport. Tel.: (057) 730-10-88. E-mail: vv1_81@mail.ru 